increased metabolic activity are predisposed to destruction by environmental factors. Hyperinsulinaemia may, however, also be the earliest manifestation of carbohydrate intolerance. A possible cause for the controversial reports on $\beta$ cell secretion in HLA identical siblings ${ }^{456}$ and the wide range of $\beta$ cell responses observed in our study, may be that this group includes probands at various stages of carbohydrate intolerance.

Long term follow up of this high risk group should clarify whether the observed $\beta$ cell responses represent a heterogeneous group of probands (with different $\beta$ cell reactivity) or two stages of preclinical carbohydrate intolerance, that may in future develop into insulin dependent diabetes.

\section{References}

1 Ilonen J, Mustonen A, Akerblom H, Huttunen $\mathbf{N}$. Complement-fixing islet-cell antibodies before and after onset of insulin dependent diabetes (letter). Lancet 1980; ii:805.
2 Gorsuch AN, Lister J, Dean BM, et al. Evidence for a long prediabetic period in type I (insulin-dependent) diabetes mellitus. Lancet 1981 ;ii:1363-5.

3 Rosenbloom AL, Hunt SS, Rosenbloom EK, MacLaren NK. Ten-year prognosis of impaired glucose tolerance in siblings of patients with insulin-dependent diabetes. Diabetes $1982 ; 31: 385-7$.

4 Barbosa J, Chavers B, Steffes M, et al. Muscle extracellular membrane immunofluorescence and HLA as possible markers of prediabetes. Lancet 1980;ii:330-3.

5 Hollander, PH, Asplin CM, Kniaz D, Hansen JA, Palmer JP. Beta-cell dysfunction in nondiabetic HLA identical siblings of insulin-dependent diabetics. Diabetes $1982 ; 31$ : 149-53.

6 Ginsberg-Fellner F, Doberson MJ, Witt ME, Rayfield EJ, Rubinstein P, Notkins AL. HLA-antigens, cytoplasmatic islet cell antibodies and carbohydrate tolerance in families with insulin-dependent diabetes mellitus. Diabetes $1982 ; 31: 392-7$.

Correspondence to Dr E Schober, Universitäts-Kinderklinik, Währingergürtel 74-76, A-1090 Wien - Austria.

Received 16 June 1983

\title{
Ineffectiveness of ipratropium bromide in acute bronchiolitis
}

\author{
R L HENRY, A D MILNER, AND G M STOKES \\ Department of Child Health, University Hospital, Queen's Medical Centre, Nottingham
}

SUMMARY In a double blind randomised trial, we found no evidence that nebulised ipratropium bromide was of clinical benefit in acute bronchiolitis.

No pharmacological agent has been shown to alter the natural history of acute viral bronchiolitis. ${ }^{12}$ Furthermore lung function studies have failed to show any objective benefit from salbutamol, orciprenaline, phenylephrine, adrenaline, and isoprenaline. ${ }^{3-5}$ We recently ${ }^{6}$ confirmed the ineffectiveness of salbutamol but found that the anticholinergic agent ipratropium bromide led to a reduction in work of breathing in 6 of 15 infants with severe bronchiolitis. This present study was designed to assess the clinical benefit of ipratropium bromide in the treatment of acute viral bronchiolitis.

\section{Patients and methods}

Sixty six children who had been admitted to hospital with acute bronchiolitis were included in the study. The diagnosis of bronchiolitis was based on the typical clinical features of a tight, irritating cough, breathlessness, respiratory distress, hyperinflation, fine crepitations, and expiratory rhonci. Respiratory syncytial virus (RSV) was isolated from $45(68 \%)$ of the children. Their average age was 130 days (range 49-368 days), 40 were boys and 26 girls.

In a randomised, double blind fashion, the children received 6 hourly nebulised solutions containing $250 \mu \mathrm{g}$ of ipratropium bromide in $2 \mathrm{ml}$ of saline (34 patients) or normal saline alone (32 patients). Treatment was stopped when the respiratory signs had resolved sufficiently for discharge home.

One of us made daily measurements of pulse and respiratory rate together with assessments of cough, rhinitis, nasal flaring, cyanosis, hyperinflation, tracheal tug, intercostal recession, subcostal recession, respiratory distress, crepitations, and rhonchi, using a four point scale scoring system for each parameter. Another of us obtained detailed information from parents and nursing staff about 
whether there was an immediate response to each nebulised treatment.

\section{Results}

The background information and clinical findings on admission to the trial were similar in the two treatment groups, with no important differences observed in any parameters. We found no evidence that ipratropium bromide altered the rate of resolution of bronchiolitis. As shown in Table 1, the number of treatments needed in each group was similar. The daily assessments reflected the clinical improvement with time. The ipratropium bromide treated group did not recover more quickly than the placebo group. Two children who received ipratropium bromide developed a tachycardia and persistent coughing with treatment, and it seems likely that treatment prolonged their illness.

Information was available from the parents of 42 children about immediate response to treatment. Based on parental assessments, 11 of 24 children treated with ipratropium bromide were helped compared with only 3 of 18 who received a placebo $\left(\chi^{2}=2 \cdot 73, P<0 \cdot 1\right)$. When we combined the opinions of the parents and nursing staff, however, the two treatment groups were very similar (Table 2).

Table 1 Number of treatments received by the 66 children before respiratory signs had resolved sufficiently for discharge home

\begin{tabular}{lcc}
\hline No of treatments & $\begin{array}{l}\text { No treated with } \\
\text { ipratropium bromide }\end{array}$ & $\begin{array}{c}\text { No treated } \\
\text { with saline }\end{array}$ \\
\hline $4-7$ & 8 & 10 \\
$8-11$ & 8 & 6 \\
$12-15$ & 9 & 10 \\
$16-19$ & 3 & 3 \\
20 or more & 6 & 3 \\
Total & 34 & 32 \\
\hline
\end{tabular}

Table 2 Immediate response to nebulised treatment, as judged by parents and nursing staff, for the 66 children

\begin{tabular}{lcc}
\hline & $\begin{array}{l}\text { No treated with } \\
\text { ipratropium bromide }\end{array}$ & $\begin{array}{l}\text { No treated } \\
\text { with saline }\end{array}$ \\
\hline Definitely helped & 7 & 6 \\
Possibly helped & 11 & 9 \\
No change & 12 & 12 \\
Possibly worse & 4 & 5 \\
Definitely worse & 0 & 0 \\
Total & 34 & 32 \\
\hline
\end{tabular}

\section{Discussion}

This clinical trial does not support the widespread introduction of ipratropium bromide in acute bronchiolitis. Furthermore, we were unable to identify a subgroup of children (such as those with a family history of asthma) who were more likely to respond to the drug than to placebo.

Our measurements were sensitive to change and we found appreciable improvements in clinical parameters when comparing the serial daily assessments. We also observed that the pulse rate fell more quickly in the placebo treated group than in the ipratropium bromide group, suggesting that the drug was being absorbed. It seems likely that our inability to show a significant benefit of ipratropium bromide over placebo, or indeed any clear trends for benefit, is a valid finding. This study provides further evidence for the ineffectiveness of bronchodilator treatment in acute bronchiolitis.

We thank the parents and consultants for allowing us to study the children and the Pharmacy department for their help. Financial assistance was provided by the Asthma Research Council, Boehringer Ingelheim, and Nestlé Paediatric Fellowship (Australia).

\section{References}

1 Leer JA, Jr, Green JL, Heimlich EM et al. Corticosteroid treatment in bronchiolitis. A controlled, collaborative study in 297 infants and children. Am J Dis Child 1969; 117:495-503.

2 Brooks LJ, Cropp GJA. Theophylline therapy in bronchiolitis. Am J Dis Child 1981 ;135:934-6.

3 Phelan PD, Williams HE. Sympathomimetic drugs in acute viral bronchiolitis. Their effect on pulmonary resistance. Pediatrics 1969;44:493-7.

4 Lenney W, Milner AD. Alpha and beta adrenergic stimulants in bronchiolitis and wheezy bronchitis in children under 18 months of age. Arch Dis Child 1978; 53:707-9.

5 Rutter N, Milner AD, Hiller EJ. Effect of bronchodilators on respiratory resistance in infants and young children with bronchiolitis and wheezy bronchitis. Arch Dis Child 1975;50:719-22.

- Stokes GM, Milner AD, Hodges IGC, Henry RL, Elphick MC. Nebulised therapy in acute severe bronchiolitis in infancy. Arch Dis Child 1983;58:279-82.

Correspondence to Professor A D Milner, Department of Child Health, Floor E, East Block, Universitv Hospital, Queen's Medical Centre, Nottingham NG7 2UH.

Received 15 August 1983 